\title{
ANALISIS FAKTOR SUKU BUNGA DAN JUMLAH UANG BEREDAR YANG BERPENGARUH TERHADAP HARGA SAHAM SEKTOR PERBANKAN
}

\author{
Abdul Rozak \\ Universitas Widyatama Bandung \\ Email : abdul.rozak@widyatama.ac.id
}

\begin{abstract}
ABSTRAK
Tujuan dalam penelitian ini yakni melakukan analisis faktor suku bunga dan jumlah uang beredar terhadap gejolak harga saham perbankan persero yang terdaftar di Bursa Efek Indonesia periode 2011-2015. Metode penelitian yang digunakan adalah explanatory research dengan deskriptif dan verifikatif. Secara empiris, hasil penelitian menunjukkan bahwa tingkat suku bunga Bank Indonesia(BI-rate) dan beredarnya uang sebagai akibat jumlah penyaluran kredit kepada masyarakat telah memberikan dampak signifikan terhadap gejolak harga saham perbankan persero. Hasil uji t menunjukkan bahwa apabila nilai tingkat suku bunga meningkat 1 satuan dengan asumsi variabel lain adalah tetap, maka akan meningkatkan harga saham sebesar 1.352. Kemudian jika nilai jumlah uang beredar meningkat 1 satuan dengan asumsi variabel lain adalah tetap, maka akan meningkatkan harga saham sebesar 67.737. Sementara hasil uji ANOVA dengan tingkat signifikansi sebesar 0.000 diperoleh nilai F hitung sebesar $54.15>$ dari F tabel sebesar 3.16. Dengan demikian secara bersama-sama variabel tingkat suku bunga dan jumlah uang beredar berpengaruh signifikan terhadap harga saham sektor perbankan persero. Implikasi dari penelitian ini akan memberikan pemahaman yang luas serta iklim investasi yang kondusif kepada masyarakat mengenai adanya faktor utama dalam mempengaruhi volatilitas harga saham secara makro.
\end{abstract}

Kata kunci : Tingkat Suku Bunga, Jumlah Uang Beredar, Harga Saham

\section{PENDAHULUAN}

Negara dengan sistem keuangan yang kuat dan modern, telah memiliki perubahan paradigma tentang uang dan cara pengalokasiannya. Hal ini sangat diperlukan guna meningkatkan pertumbuhan ekonomi di masa mendatang. Sektor yang memiliki peranan aktif dalam pembangunan ekonomi pada suatu negara adalah sektor perbankan. Sektor ini diharapkan dapat berkembang dengan pesat guna menghadapi era persaingan global serta perkembangan investasi pada pasar keuangan Indonesia. Investasi pada pasar keuangan terbagi atas dua bagian yaitu pada institusi Pasar Modal maupun Pasar Uang. Pasar modal memiliki 2 fungsi utama, yaitu: pertama sebagai tempat bagi perusahaan dalam memperoleh dana masyarakat pemodal. Dana tersebut dapat digunakan untuk pengembangan usaha, ekspansi serta penambahan modal kerja. Kedua, menjadikan unsur masukan atau saran bagi masyarakat umum dalam melakukan investasi di berbagai tambahan instrumen keuangan lain, misalnya: saham, obligasi dan reksadana. Aktivitas pada lembaga bursa efek sangat dipengaruhi oleh faktor eksternal dan internal. Faktor eksternal merupakan suatu hal yang tidak dapat dikendalikan oleh institusi perusahaan, contohnya: tingkat suku bunga, jumlah uang yang beredar, nilai tukar, serta kondisi ekonomi. Sedangkan faktor internal merupakan sesuatu hal yang masih dapat dikendalikan oleh institusi perusahaan, seperti: kinerja karyawan dan teknologi mesin. Perubahan yang terjadi atas faktor eksternal dan internal akan direspon cepat oleh pasar, sehingga berpotensi terhadap fluktuasi resiko dalam berinvestasi. Tingkat pada domain suku bunga akan memiliki pengaruh terhadap gejolak harga saham secara tak langsung (Aditya, 2013:421-435). Contohnya: jika harga surat berharga atau saham mengalami kenaikan atau penurunan akibat gejolak suku bunga maka kemungkinan investor akan mengalami capital loss atau capital gain. Saat ini bank indonesia telah menurunkan tingkat suku bunga acuan menjadi $6.75 \%$. Kebijakan ini ditempuh agar semua bank umum dapat menurunkan tingkat suku bunga kreditnya guna peningkatan laju pertumbuhan ekonomi dan peningkatan daya beli dikalangan masyarakat. 
Dengan adanya kenaikan tingkat suku bunga, berdampak pada sensitifnya sektor perbankan. Masyarakat akan lebih mengutamakan dalam menyimpan uangnya sehingga akan berdampak pada biaya simpanan yang cukup besar dikeluarkan oleh pihak bank. Sementara pemahaman tentang jumlah uang yang beredar dapat pula diartikan secara sempit maupun luas. Adapun pengertian secara sempit, uang yang senantiasa beredar di masyarakat terdiri atas uang kartal sedangkan dalam arti luas disebut sebagai uang kuasi. Tinjauan terhadap hasil penelitian oleh para peneliti sebelumnya menunjukkan adanya faktor jumlah uang yang beredar ini berpengaruh secara signifikan terhadap tingkat perubahan harga saham. Hal ini terjadi akibat adanya tekanan inflasi yang memberikan dampak terhadap naik turunnya keuntungan perusahaan (Divianto, 2013:165-197). Ketika inflasi tinggi dan jumlah uang yang beredar di masyarakat banyak, Bank Indonesia secara otomatis akan merespon dengan menekan tingkat suku bunganya. Dengan tingkat suku bunga yang tinggi, masyarakat cenderung lebih memillih investasi di bank karena akan mendapatkan keuntungan dari bunganya. Namun sebaliknya jika tingkat suku bunga rendah, investor akan cenderung lebih memilih investasi pada pasar modal. Meskipun adanya peningkatan inflasi akibat jumlah uang yang beredar tinggi, minat masyarakat indonesia dalam berinvestasi pun ternyata masih belum banyak. Pemaparan dalam fenomena yang terjadi, menunjukkan adanya permasalahan yang diakibatkan oleh pengaruh faktor tingkat pada suku bunga dan jumlah frekuensi uang beredar terhadap gejolak harga saham di sektor perbankan persero. Penelitian ini penting dilakukan untuk mengetahui pengaruh kedua variabel, yakni tingkat suku bunga dan jumlah uang beredar terhadap gejolak harga saham yang diduga memiliki kesenjangan berarti selama periode observasi akibat adanya tekanan inflasi, tingkat daya beli masyarakat serta kurangnya pemahaman yang komprehensif tentang paradigma berinvestasi pada instrumen yang tepat.

\section{Pengaruh Tingkat Suku Bunga dengan Harga Saham}

Suku bunga adalah suatu hal masukan penting dalam melakukan keputusan investasi. Apabila suku bunga turun, orang cenderung memilih untuk melakukan investasi jangka panjang. Sedangkan disaat suku bunga mengalami kenaikan, orang akan memilih berinvestasi untuk jangka yang pendek. Novianto berpendapat (2011:11), bahwa suku bunga ditentukan pula oleh adanya suatu permintaan atau penawaran terhadap uang. Gejolak adanya perubahan pada tingkat suku bunga akan mempengaruhi iklim investasi, dimana harga-harga dapat mengalami kenaikan atau penurunan pada tingkat bunga sehingga memungkinkan para pemegang surat berharga akan mengalami kerugian ataupun keuntungan. Apabila tingginya tingkat suku bunga, investor cenderung menanamkan modalnya kedalam bentuk tabungan atau deposito, atau dapat pula membeli instrumen obligasi yang memberikan bunga tetap, sehingga kemungkinan pasar bursa saham mengalami kelesuan. Namun sebaliknya apabila rendahnya tingkat suku bunga, kecenderungan dana akan mengalir ke pasar bursa saham.

\section{Pengaruh Jumlah Uang Beredar dengan Harga Saham}

Prospek perusahaan ditinjau dari proses kinerjanya yang dipengaruhi oleh berbagai variabel makro yang tidak terkendali. Jika terjadi gejolak pergeseran variabel tersebut, maka akan berhubungan dengan naik atau turunnya harga pasar saham. Tingkatan pada suku bunga memiliki pengaruh terhadap proses aktvitas dibursa saham. Tingkat suku bunga ini pun sangat ditentukan oleh permintaan atau penawaran terhadap uang (Kumalasari, 2016:8-15). Selanjutnya akan mempengaruhi keputusan investor dalam berinvestasi. Misalkan pada instrumen surat berharga, dapat mengalami kenaikan/penurunan nilainya tergantung oleh tingkat suku bunga sehingga memungkinkan para pemegang surat berharga akan mengalami kerugian atau keuntungan. Jika tingkat suku bunga tinggi, para pemilik uang cenderung menyimpannya ke dalam tabungan atau deposito. Ataupun sebaliknya apabila rendah tingkat suku bunga, cenderung akan memilih pasar 
saham. Dengan demikian hubungan tingkatan suku bunga dan saham memiliki hubungan yang negatif (Novianto, 2011:11). Adapun faktor variabel makro lainnya yakni jumlah uang beredar. (Nugroho, 2008) berpendapat dalam penelitiannya, bahwa jumlah uang beredar berpengaruh signifikan terhadap indeks harga pasar saham. Hal ini dikarenakan uang yang beredar di indonesia sudah mulai dimanfaatkan oleh masyarakat dalam rangka investasi pada pasar modal.

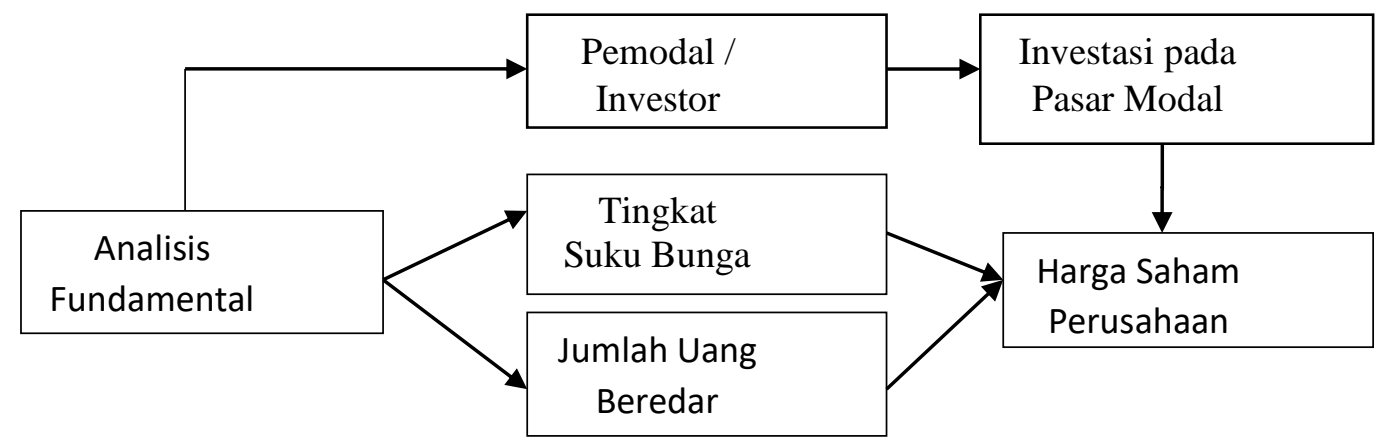

Gambar 1. Alur Kerangka Pemikiran

\section{METODE PENELITIAN}

Metode deskriptif dan verifikatif digunakan dalam penelitian ini. Penelitian deskriptif merupakan suatu teknik dalam meneliti status kelompok manusia, objek, kondisi, ataupun kelompok peristiwa dimasa sekarang. Tujuannya yaitu membuat deskripsi atau lukisan secara sistematis, faktual dan akurat tentang fakta, sifat dan hubungan antar fenomena (Nazir, 2003:54). Sedangkan penelitian verifikatif bertujuan dalam menganalisis hubungan kasualitas antar suatu variabel sehingga diperoleh hasil pembuktian yang menunjukkan ditolak atau diterima (Rasyad, 2003:12). Pemahaman peneliti mengenai metode penelitian deskriptif yakni menggambarkan keadaan di lapangan secara sistematis dengan fakta-fakta dengan interprestasi yang tepat, serta bukan hanya untuk mencari kebenaran mutlak tetapi pada hakekatnya mencari pemahaman observasi.

Dalam penelitian ini, pendekatan deskriptif digunakan untuk menjawab fenomena serta permasalahan yang terjadi fluktuasi suku bunga dan jumlah uang yang beredar di masyarakat terhadap gejolak harga saham selama periode pengamatan. Sementara pendekatan verifikatifnya adalah ingin menguji kebenaran dari hipotesis yang dilaksanakan melalui data-data yang tersedia dengan penerapan analisis analisis regresi berganda, uji t dan uji F. Operasional suatu variabel merupakan cara untuk mengestimasi konsep sehingga diperoleh hasil yang dapat mempengaruhi atau dipengaruhi, yakni faktor variabel penyebab masalah serta faktor variabel lainnya. Adapun variabel yang digunakan dalam penelitian ini yaitu :

\section{Variabel bebas $(\mathrm{X})$ atau independent variable}

Variabel bebas merupakan faktor yang berpengaruh atau menjadi penyebab perubahan atas variabel terikat. Untuk penelitian ini variabel bebasnya adalah tingkat faktor suku bunga dan jumlah uang beredar.

2. Variabel Terikat (Y) atau dependent variable

Variabel terikat merupakan variabel yang disebabkan oleh adanya pengaruh atas variabel bebas. Untuk penelitian ini faktor variabel terikatnya adalah harga saham yang merupakan panduan bagi investor guna berinvestasi di pasar modal. 
Tabel 1. Operasionalisasi Variabel Dalam Penelitian

\begin{tabular}{|c|c|c|c|c|}
\hline Variabel & Definisi Operasional & Indikator & Satuan & Skala Ukur \\
\hline $\begin{array}{c}\text { Tingkat Faktor Suku } \\
\text { Bunga }\end{array}$ & $\begin{array}{l}\text { Suku bunga SBI merupakan } \\
\text { tingkat suku bunga yang } \\
\text { dinyatakan dan ditentukan oleh } \\
\text { Bank Indonesia. Suku bunga ini } \\
\text { digunakan dalam masa } 1 \text { bulan } \\
\text { dan pengukurannya dinyatakan } \\
\text { dalam satuan persen. }\end{array}$ & Bi rate & Persen & Rasio \\
\hline $\begin{array}{c}\text { Jumlah Uang Yang } \\
\text { Beredar }\end{array}$ & $\begin{array}{l}\text { Jumlah satuan uang yang beredar } \\
\text { per tahun dalam milyar rupiah } \\
\text { dihitung berdasarkan jumlah M2 } \\
\text { untuk periode } 2011-2015\end{array}$ & M1 dan M2 & Rupiah & Rasio \\
\hline Harga Saham & $\begin{array}{l}\text { Harga perlembar saham } \\
\text { perusahaan sektor perbankan } \\
\text { persero yang diperjualbelikan di } \\
\text { pasar modal }\end{array}$ & $\begin{array}{c}\text { Harga penutupan } \\
\text { seriode } 2011-2015\end{array}$ & Rupiah & Rasio \\
\hline
\end{tabular}

Sumber data yang diterapkan dalam penelitian ini berasal dari data sekunder laporan keuangan lembaga perusahaan go public di bursa efek indonesia periode 2011 - 2015. Teknik samplingnya menggunakan metode purposive sampling. Yang menjadi Sampelnya adalah seluruh populasi dalam penelitian, yaitu perusahaan pada sektor perbankan telah terdaftar di bursa efek indonesia serta memenuhi kriteria tertentu.

Tabel 2. Tabel Rata-rata Harga Saham Perbankan Persero

\begin{tabular}{|c|c|c|c|c|}
\hline Tahun & Mandiri & BTN & BNI & BRI \\
\hline 2011 & $\mathrm{Rp} \quad 6.775,00$ & Rp 1.424,58 & Rp 3.872,92 & $\mathrm{Rp} \quad 6.158,33$ \\
\hline 2012 & $\mathrm{Rp} \quad 7.533,33$ & Rp 1.340,83 & Rp 3.818,75 & $\mathrm{Rp} \quad 6.845,83$ \\
\hline 2013 & $\mathrm{Rp} \quad 8.862,50$ & Rp 1.228,33 & Rp 4.433,33 & $\mathrm{Rp} \quad 8.075,00$ \\
\hline 2014 & $\mathrm{Rp} \quad 9.898,75$ & $\mathrm{Rp} 1.114,17$ & Rp $5.189,58$ & $\operatorname{Rp} 10.377,08$ \\
\hline 2015 & $\mathrm{Rp} 10.004,17$ & Rp 1.150,83 & Rp 5.591,67 & $\mathrm{Rp} 11.131,25$ \\
\hline
\end{tabular}

Sumber : www.idx.co.id

\section{Metode Dalam Analisis Data}

Metode dalam analisis data yang diterapkan yaitu analisis korelasi dan regresi linier berganda. Analisis pengujiannya dilakukan secara verifikatif dalam menjelaskan apakah terdapat pengaruh tingkat faktor suku bunga dan jumlah uang yang beredar terhadap harga pasar saham. Berikut ini penjelasan masing-masing analisis datanya :

\section{Analisis Korelasi Berganda}

Analisis korelasi berganda diterapkan dalam mencari hubungan antar 2 variabel bebas atau lebih secara simultan dikaitkan dengan variabel terikat, yang pada akhirnya akan diketahui arah dan kuatnya hubungan tersebut. Koefisien korelasi berganda (R) dengan empat variabel bebas dan satu variabel terikat dapat dihitung dengan formula sebagai berikut : 


$$
R y(1,2)=\sqrt{\frac{b 1 \sum X I Y+B 2 \sum \quad X 2 Y}{\sum Y 2}}
$$

Sumber : Buku Metode Penelitian Kuantitatif dan Kualitatif Tahun 2012

\section{Analisis Koefisien Determinasi}

Koefisien determinasi $\left(\mathrm{R}^{2}\right)$ pada intinya mengukur seberapa jauh kemampuan model dalam menerangkan variasi variabel independen. Nilai koefisien determinasi adalah antara nol dan satu. Nilai $\mathrm{R}^{2}$ yang kecil berarti kemampuan variabel independen dalam menjelaskan variasi variabel dependen amat terbatas. Nilai yang mendekati satu berarti variabel independen memberikan hampir semua informasi yang dibutuhkan untuk memprediksi variasi variabel dependen (Ghozali, 2011:105).

\section{Analisis Regresi Berganda}

Persamaan regresi berganda yang diaplikasikan kedalam pola penelitian ini dilakukan untuk mengetahui adanya pengaruh faktor suku bunga dan jumlah uang yang beredar terhadap harga pasar saham. Pola persamaannya adalah $\mathbf{Y}=\boldsymbol{a}+\boldsymbol{b}_{1} \boldsymbol{X}_{\boldsymbol{1}}+\boldsymbol{b}_{2} \boldsymbol{X}_{2}+\boldsymbol{e}$

\section{Pengujian Hipotesis}

Kesesuaian fungsi regresi guna menaksir nilai sebenarnya dapat diukur melalui istilah Goodness of Fit-nya. Dalam ilmu statistik, diukur berdasarkan nilai koefisien determinasi, nilai pengujian $\mathrm{t}$ dan F. Perhitungan angka statistik dapat dikategorikan signifikan jika nilai uji statistiknya berada pada daerah kristis (Ho ditolak). Sebaliknya, dapat dikategorikan tidak signifikan jika nilai uji statistiknya berada pada daerah Ho yang diterima (Ghozali, 2011:97).

\section{a. Uji Simultan (Uji Statistik F)}

Pengujian nilai statistik F menunjukkan tentang apakah variabel independen / bebas yang diteliti kedalam model memiliki pengaruh secara simultan terhadap variabel dependennya. Hipotesis nol (Ho) yang akan diuji adalah mengenai apakah parameter dalam model harus $=0$, atau hipotesis alternatif $(\mathrm{Ha})$ tidak semua parameternya secara simultan $=0$ (Ghozali, 2011:160).

\section{b. Uji Parsial (Uji Statistik t)}

Pengujian nilai statistik t menunjukkan tentang seberapa besar pengaruh satu variabel independen/bebas secara individual dalam menjelaskan variabel dependennya (Ghozali, 2011:105).

\section{HASIL DAN PEMBAHASAN}




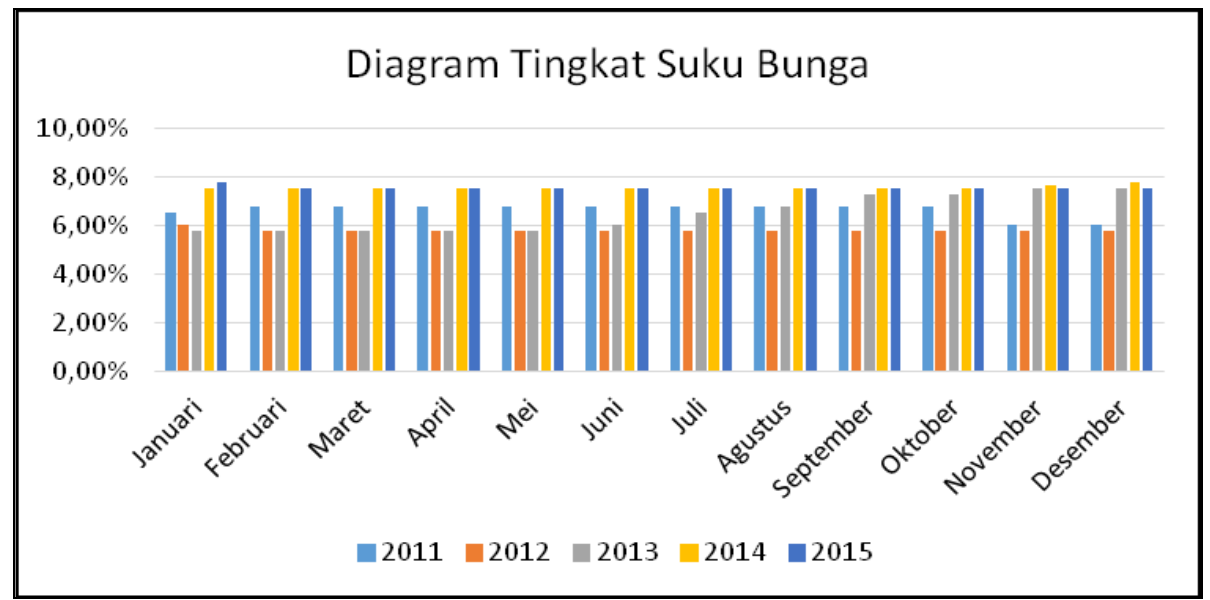

Gambar 2. Volatilitas Tingkat Suku Bunga

Sumber: www.bi.go.id

Pada gambar 2. Volatilitas faktor suku bunga, dapat diketahui bahwa nilai tertinggi pada faktor ini adalah $7.75 \%$ yakni terjadi pada bulan Januari 2014. Sementara nilai terendahnya sebesar 5.75\% yakni pada bulan Februari 2012 hingga Mei 2013. Besarnya rata-rata peningkatan suku bunga setiap tahunnya sebesar $6.60 \%$ pada $2011,5.77 \%$ pada $2012,6.46 \%$ pada $2013,7.53 \%$ pada 2014, dan 7.52\% pada 2015. Hasil rapat dewan gubernur Bank Indonesia tanggal 17 Februari 2015 menentukan untuk menurunkan Bi rate 25 bps menjadi 7.5\%, dengan faktor suku bunga deposito turun 25 bps menjadi 5.5\% dan faktor fasilitas kreditnya pun tetap di level $8 \%$ berlaku efektif sejak tanggal 18 Februari 2015. Kebijakan ini diputuskan dengan keyakinan bahwa inflasi akan terkendali. Kebijakan ini pun masih sejalan dalam upaya Bank Indonesia mengendalikan angka defisit transaksi berjalan pada tingkat yang lebih sehat. Bank Indonesia mengapresiasi atas kebijakan reformasi subsidi energi, kemudian rencana pembangunan infrastuktur, serta perbaikan iklim investasi termasuk pada pelayanan terpadu perijinan satu pintu.

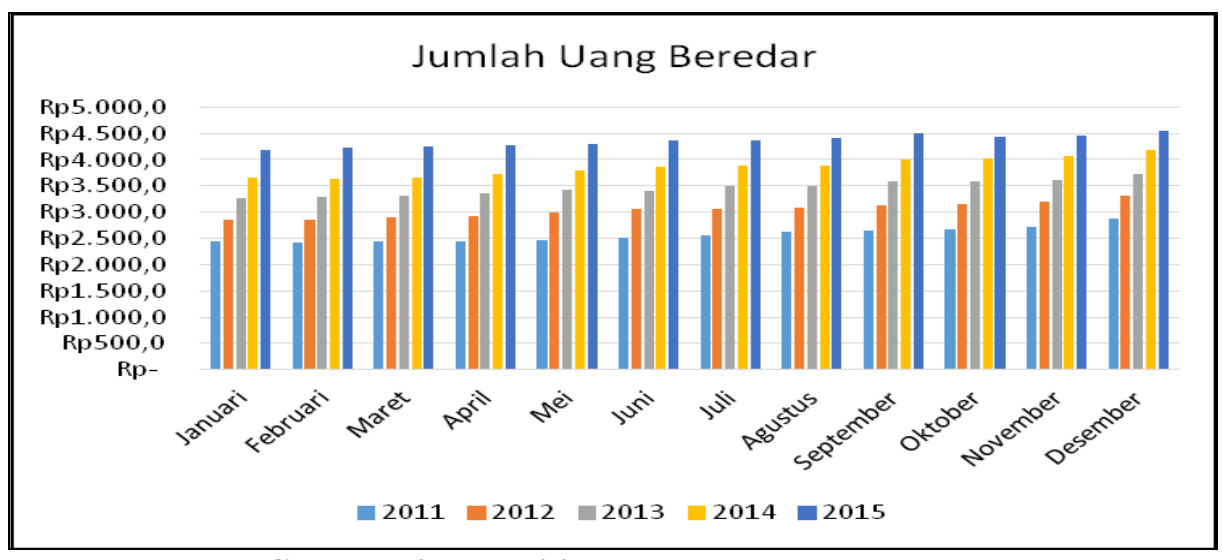

Gambar 3. Volatilitas Jumlah Uang Beredar

Sumber : www.bi.go.id

Sementara pada gambar 3. Volatilitas jumlah uang yang beredar menunjukkan bahwa nilai terendahnya terdapat pada bulan Februari 2011 Rp. 2.420,4 (triliun rupiah). Sedangkan nilai tertingginya pada bulan Desember 2015 Rp. 4.548,8 (triliun rupiah). Besarnya rata-rata jumlah uang beredar tahun 2011 sebesar Rp. 2.571,2 (triliun rupiah), tahun 2012 Rp. 3.043,9 (triliun rupiah), tahun 2013 Rp. 3.465,3 (triliun rupiah), tahun 2014 Rp. 3.866,4 (triliun rupiah), dan terakhir pada tahun 2015 Rp. 4.357,7 (triliun rupiah). Jumlah uang yang beredar pada permulaan bulan Januari 2015 hingga Desember 2015 terus mengalami peningkatan. Hal ini dipengaruhi oleh semakin meningkatnya penyaluran kredit kepada masyarakat. Tercatat penyaluran kreditnya 


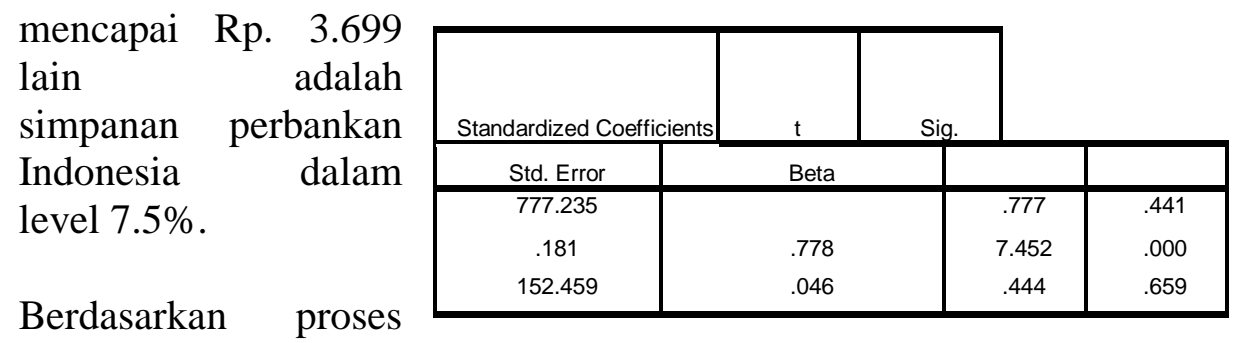

(triliun rupiah). Faktor menurunnya bunga seiring kebijakan Bank menurunkan Bi rate ke

Berdasarkan proses

Model Summary

\begin{tabular}{|l|c|c|c|c|c|}
\hline Model & & & & \\
& $\mathrm{R}$ & $\mathrm{R}$ Square & Adjusted R Square & Std. Error of the Estimate & Durbin-Watson \\
\hline dimension0 1 & $.800^{\mathrm{a}}$ & .655 & .643 & 667.77605 & .502 \\
\hline \\
$\begin{array}{l}\text { a. Predictors: (Constant), Suku Bunga, Uang Beredar } \\
\text { b. Dependent Variable: Harga Saham }\end{array}$
\end{tabular}

diperoleh hasil untuk pengujian koefisien korelasi berganda dan koefisien determinasi sebagai berikut :

Tabel 3. Koefisien Korelasi Berganda \& Koefisien Determinasi

Hasil analisis korelasi berganda menunjukkan angka koefisien korelasi sebesar 0.809. Hal ini menyatakan adanya keeratan hubungan kuat antar variabel suku bunga, jumlah uang yang beredar dan harga pasar saham. Hasil analisis koefisien determinasi berdasarkan angka Adjusted $R$ Square $0,643=64.3 \%$ menunjukkan besarnya pengaruh faktor suku bunga, jumlah uang yang beredar sebesar $64.3 \%$ terhadap harga pasar saham. Sementara itu, berdasarkan hasil analisis regresi berganda dalam mengetahui pengaruh faktor suku bunga, jumlah uang yang beredar terhadap harga pasar saham secara simultan, sebagaimana dapat dilihat pada tabel berikut ini :

Tabel 4. Analisis Regresi Berganda

\begin{tabular}{|c|c|c|c|c|c|}
\hline \multicolumn{6}{|l|}{ Model } \\
\hline & \multicolumn{2}{|c|}{ Unstandardized Coefficients } & Standardized Coefficients & & \\
\hline & $\mathrm{B}$ & Std. Error & Beta & $\mathrm{t}$ & Sig. \\
\hline $1 \quad$ (Constant) & 603.665 & 777.235 & & .777 & .441 \\
\hline Suku Bunga & 1.352 & .181 & .778 & 7.452 & .000 \\
\hline Uang Beredar & 67.737 & 152.459 & .046 & .444 & .659 \\
\hline
\end{tabular}

Sumber : Hasil Olah Data 
Formulasi model persamaan regresi berganda adalah $\mathrm{Y}=603.665+1.352 \mathrm{X}_{1}+67.737 \mathrm{X}_{2}$ menunjukkan bahwa apabila nilai tingkat suku bunga meningkat 1 satuan dengan asumsi bahwa variabel lainnya tetap, akan meningkatkan harga pasar saham sebesar 1.352. Sementara itu jika nilai jumlah uang beredar meningkat 1 satuan dengan asumsi bahwa variabel lainnya juga tetap, akan meningkatkan harga pasar saham sebesar 67.737. Pengujian statistik secara simultan diaplikasikan guna mengetahui nilai prediksi kuatnya hubungan antar 2 variabel/lebih secara bersamaan. Hasil pengujiannya (uji statistik F) dapat dilihat pada tabel berikut ini :

Tabel 5. Uji hipotesis (uji F)

\begin{tabular}{|l|c|c|c|c|c|}
\hline Model & Sum of Squares & Df & Mean Square & F & Sig. \\
\hline $1 \quad$ Regression & 4.8297 & 2 & 2.4147 & 54.145 & $.000^{\mathrm{a}}$ \\
& 2.5427 & 57 & 445924.857 & & \\
Residual & 7.3717 & 59 & & & \\
Total & a. Predictors: (Constant), Suku Bunga, Uang Beredar \\
b. Dependent Variable: Harga Saham
\end{tabular}
a

Sumber : Hasil Olah Data

Nilai $F$ hitung dari tabel output ANOVA di atas, yaitu 54.145 menunjukkan hasil perbandingan antara $\mathrm{F}$ hitung dengan $\mathrm{F}$ tabel dengan Ho ditolak, karena nilai $\mathrm{F}$ hitung $54.145>\mathrm{F}$ tabel 3.16 . Begitupun dengan nilai signifikansi 0.000 secara bersama-sama faktor tingkat suku bunga dan jumlah uang yang beredar memiliki pengaruh signifikan terhadap pergerakan harga pasar saham pada perbankan persero.

\section{KESIMPULAN}

Tingkat suku bunga dan jumlah uang yang beredar berpengaruh cukup besar terhadap gejolak pergerakan harga pasar saham. Hal ini dikarenakan faktor tersebut memiliki sensitifitas tinggi meskipun acuan yang digunakan bukan tingkat suku bunga pada tiap bank, akan tetapi berdasarkan pada acuan tingkat suku bunga bank sentral melalui nilai BI-rate.

Secara empiris, telah terbukti bahwa tingkat suku bunga yang telah dikeluarkan oleh bank sentral(BI-rate) dan beredarnya uang sebagai akibat jumlah penyaluran kredit kepada masyarakat telah memberikan dampak signifikan terhadap gejolak harga saham perbankan bagi pergerakan pola investasi secara makro. Tekanan inflasi, daya beli masyarakat serta kurangnya pemahaman akan berinvestasi di masyarakat menjadi faktor penunjang adanya kesenjangan permasalahan yang timbul selain pada faktor utamanya. Oleh karena itu dengan adanya bukti-bukti empiris yang telah diobservasi, akan memberikan pola pemahaman yang lebih komprehensif serta menjawab tujuan dari penelitian ini yakni mengetahui besarnya pengaruh faktor utama terhadap gejolak harga saham secara statistik. Pada akhirnya, penelitian ini akan memberikan manfaat berarti bagi kalangan praktisi, investor dan segmen masyarakat lainnya yang berkepentingan.

\section{REFERENSI}

Aditya, Anak Agung Gde \& Ni Gusti Putu Wirawati. (2013). Pengaruh Inflasi, Nilai Tukar Rupiah, Suku Bunga SBI Pada Indeks Harga Saham Gabungan di BEI : Jurnal Akuntansi Udayana Vol. 3 No. 2, 421-435

Divianto. (2013). Analisis Pengaruh Tingkat Inflasi, Tingkat Suku Bunga SBI, dan Nilai Kurs USD Terhadap Indeks Harga Saham Gabungan (IHSG) di BEI : Jurnal Ekonomi dan Informasi Akuntansi (JENIUS) Vol.3 No. 2, 165-197

Ghozali, Imam. (2011). Aplikasi Analisis Multivariate dengan Program SPSS. Semarang : Badan Penerbit UNDIP. 
Kumalasari, Dewi. (2016). Pengaruh Nilai Tukar (Kurs) USD/IDR, Tingkat Suku Bunga SBI, Inflasi dan Jumlah Uang Yang Beredar (M2) Terhadap Indeks Harga Saham Gabungan (IHSG) di Bursa Efek Indonesia : Jurnal Akademika Vol.14 No. 1, 8-15

Nazir, Muhamad. (2003). Teori Makro Ekonomi. Jakarta: Ghalia Indonesia.

Novianto, Aditya. (2011). Analisis Pengaruh Nilai Tukar Dollar / Rupiah, Tingkat Suku Bunga, Inflasi dan Jumlah Uang Yang Beredar Terhadap Indeks Harga Saham Gabungan. Semarang : UNDIP.

Nugroho, Heru. (2008). Analisis Pengaruh Inflasi, Suku Bunga, Kurs dan Jumlah Uang Yang Beredar Terhadap Indeks LQ45 Periode 2002-2007. Tesis Studi Magister Manajemen. Semarang : UNDIP.

Rasyad, R. (2003). Metode Statistika Deskriptif Untuk Umum. Jakarta : Penerbit Grasindo. 